\title{
Women in Rural Development: An Appraisal of Yam Chips Processors in Saki Area Oyo State, South West Nigeria
}

\author{
Siyanbola, Mojisola Funmilayo (Mrs.)
}

\author{
Agricultural Technology Department, The Polytechnic, Ibadan, Nigeria \\ mojisiyanbola@vahoo.com
}

\begin{abstract}
An investigation was carried out to appraise the processing of yam chips in Saki Area of Oyo State, South West, Nigeria. Purposive stratified random samplings of 150 respondents in 8 processing centres using structured questionnaire were adopted. Descriptive statistics (frequency and percentages) were used to analyse the socio-economic variables while chi-square was used to capture the relationship that exists between socio-economic factors and output, and also between year of experience and output. However, the study revealed that $95 \%$ of the processors were females with age ranging between 20-60 years. Majority of the processors (76\%) were married, while $43 \%$ had junior and secondary school education. Eighty-five percent of the processors were Muslims. Using chi-square, all the tested socio-economic variables had no statistical effects on output and socio - economic characteristics of the processors. The study also revealed factors militating against large scale production of yam chips in this area of study. Recommendations such as provision of loan and credit facilities, provision of modern equipment and social amenities were suggested in order to increase production thus assisting in alleviating poverty in this area.
\end{abstract}

Keywords- Yam chips, Processors, Poverty, Rural Development, Dioscorea spp.

\section{INTRODUCTION}

Yam (Dioscorea spp) is an important source of carbohydrate for many people of the sub-Saharan region especially in the yam zone of West Africa (Akissoe et al, 2003). Yam belongs to the genus Dioscorearotundata, D. cayensis, D. alata, D. dumetorum and D. esculenta (Coursey, 1967). The tuber is economically the most important part of the plant. Yam is an impotant food crop especially in the yam zones of West -Africa comprising Cameroon, Nigeria, Benin, Togo, Ghana and Cote D 'Ivoire .This zone produces more than $90 \%$ of the total production which is estimated at about 20-25 million tons per year (Sanusi and Salimonu,
2006).Nigeria is the main producer of yam in the word with about $71 \%$ of the word output followed by Ghana,Cote d' Ivoire, Benin and Togo (FAO,2002). Yam production in Nigeria has tripled over the past 40 years from 6.7 million tonnes per annum in 1961 to 27 million tonnes per annum in 2001 (FAO, 1999) and 35.017 million tonnes per annum in 2008 (FAO, 2010). These figures account for $68.0 \%$ of the world population in 2008 thus making Nigeria the largest producer in the world (FAO, 2010).

Yam production was indigenous to the forest areas of the country (Coursey and Coursey, 1971; Hahn et al, 1987) but in recent times, yam production has shifted to Guinea and even Sudan Savanna zones due to shortage of arable land in the forest areas under increasing population pressure (Manyong and Oyewole, 1997). Yam has some inherent characteristics which make it attractive and it is rich in carbohydrate especially starch and moreover has multiplicity of end use (FAO, 1987). Yam could be eaten as boiled yam or fried in oil. It can also be processed into yam chips. Moreover, yam is also a source of industrial starch, although the quality of starch of some species is said to be comparable to cereal starchy (Osisiogu and Uzo, 1973).The major constraint is that yam is a perishable food item. The tubers cannot be store for more than a few weeks after harvesting. Moulds and bacterial have been implicated in the deterioration of stored yam. A loss of $10-15 \%$ in the first three months and losses approaching 50\% after six months storage have been reported by Coursey (1967) and Asiedu (1989). However, the processing of yam tubers into staple non-perishable and easily transportable chips offers an alternative storage in fresh form. The stages of yam chips processing involves the peeling of the epidermis of the tubers, slicing the tuber to thickness of about $1 \mathrm{~cm}$, parboiling the yam slices (for $30 \mathrm{~min}$ at $70^{\circ} \mathrm{C}$ ) and finally sun drying for about 4-10 days to reduce the moisture content to about $10 \%$. The parboiling of the slices softens the tissue considerable and gives a more palatable production. However, Ezeh 1992 
reported that it is not in all cases that the tubers are parboiled especially in Nigeria.

The microbiological quality of chips is closely related to the rate of drying. Processing occurs within the periods of harmattan, with a very dry wind coming from Sahara during the dry season (Akissoe et al 2006). Yam chips are stabilised with a moisture of about 10 to $13 \%$ as against $60-75 \%$ in fresh tubers and can be kept for up to a year when stored in water insect proof condition. Yam chips are competitive with respect to other starchy products. The chips are mainly eaten in paste form prepared from the flour obtained by grinding them (Vierner et al, 2010). The flour can be turned into granules or mixed with biscuits as weaning food for babies.

In Nigeria, women play a vital role in providing food and nutrition for their family through their roles as food producers, processors, traders and income earners (Siyanbola
\& Elegbede, 2008). Although, still using traditional methods which are tedious and often inefficient. The involvement of women in food processing and storage has assisted a lot to reduce spoilage and wastage which usually lead to a reduction in national income and nutrition standards and substantial reduction in the ratio of food supply (Olatoye, 1989). Production of yam chips may act as a catalyst to food production with the rapid pace of urbanization in Nigeria. This can be through the development of sustainable intermediation system (marketing, transportation and processing between urban and rural areas.These systems should be able to guarantee outlets for farmers ,thereby encouraging them to increase production and at the same time available on a permanent basis products that are adapted to the eating habits and budget of urban consumers . The tradition processing method has become popular over the years in the South-Western part of Nigeria.

\section{Fresh Tubers $(3-5 \mathrm{~kg})(35-40 \%$ d.m.)}

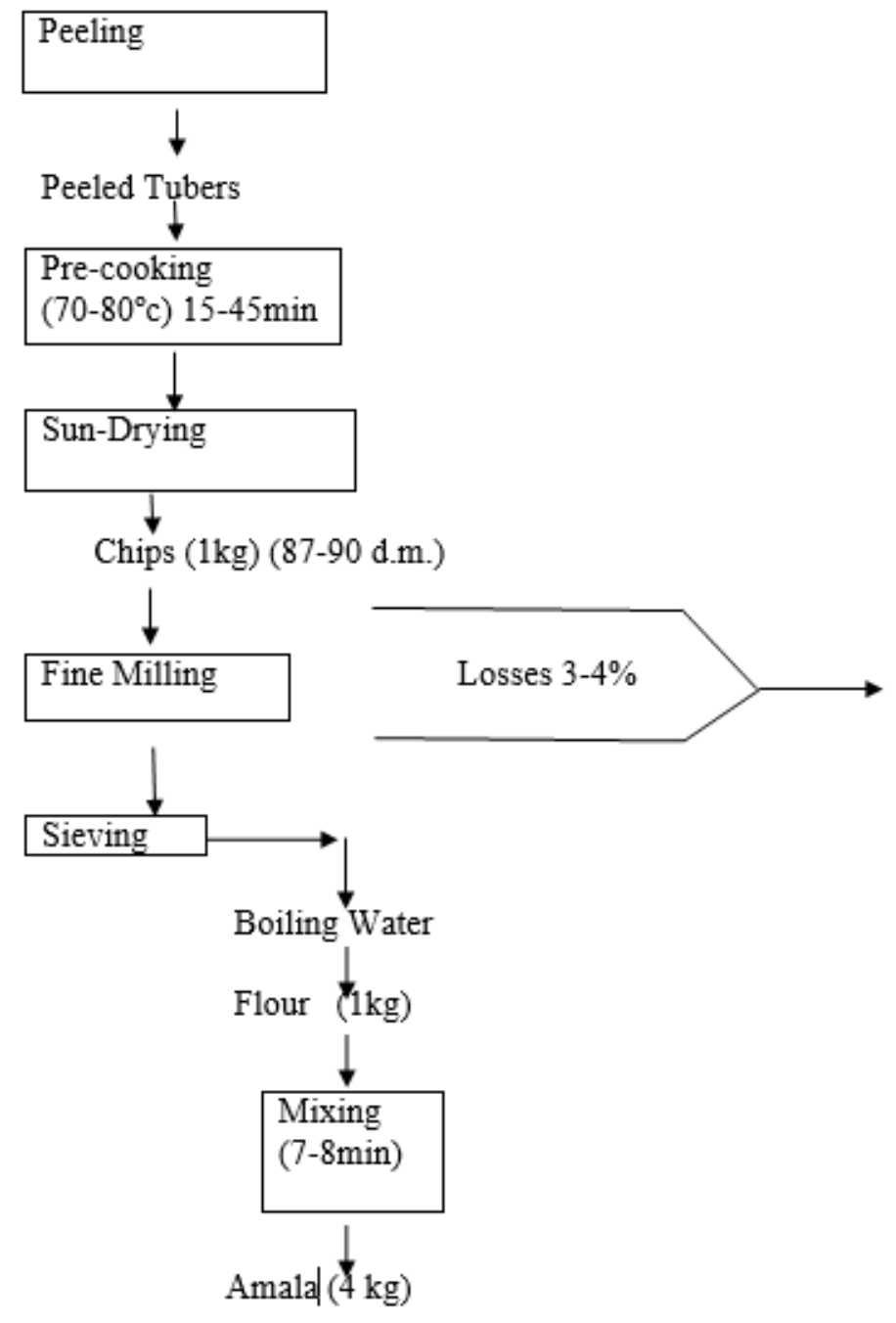

Fig.2: The processing of yam tubers into chips, flour and "Amala" 
Objectives of the Study

Specific objectives of this study are:

i. To describe the socio-economic characteristics of the yam chips processors in Saki Area of Oyo State, Nigeria.

ii. To appraise the level of yam chips production in Saki Area of Oyo State, Nigeria.

iii. To identify reasons for women involvement in chips processing.

iv. To identify constraints faced by yam chips processors in this area.

v. To examine the relationship between the socioeconomic factors and output.

vi. To determine the occupational hazards of yam chips production.

vii. To make recommendations.

\section{METHODOLOGY}

\section{Sampling Procedure and Data Collection}

This study was conducted at eight processing centers at Saki, Area of Oyo State, South- West Nigeria. ( Fig 2.) A trial survey was conducted from October 2009 to February 2010 while the final survey was carried out from October 2010 to February 2011. Saki is situated on Longitude $03^{\circ} 4 \mathrm{E}$ and Latitude $8^{\circ} 75 \mathrm{~N}$. It is about $180 \mathrm{~km}$ North West Ibadan. About $80 \%$ of the people of this area are predominantly farmers planting mainly tuber crops such as yams, cassava and cereals. The climate of the study area is tropical climate with a moderate annual rainfall .The raining season lasts for 8-9 months with a short dry season of 3-4 months .The mean annual temperature is about 80 For $27 \mathrm{C}$.

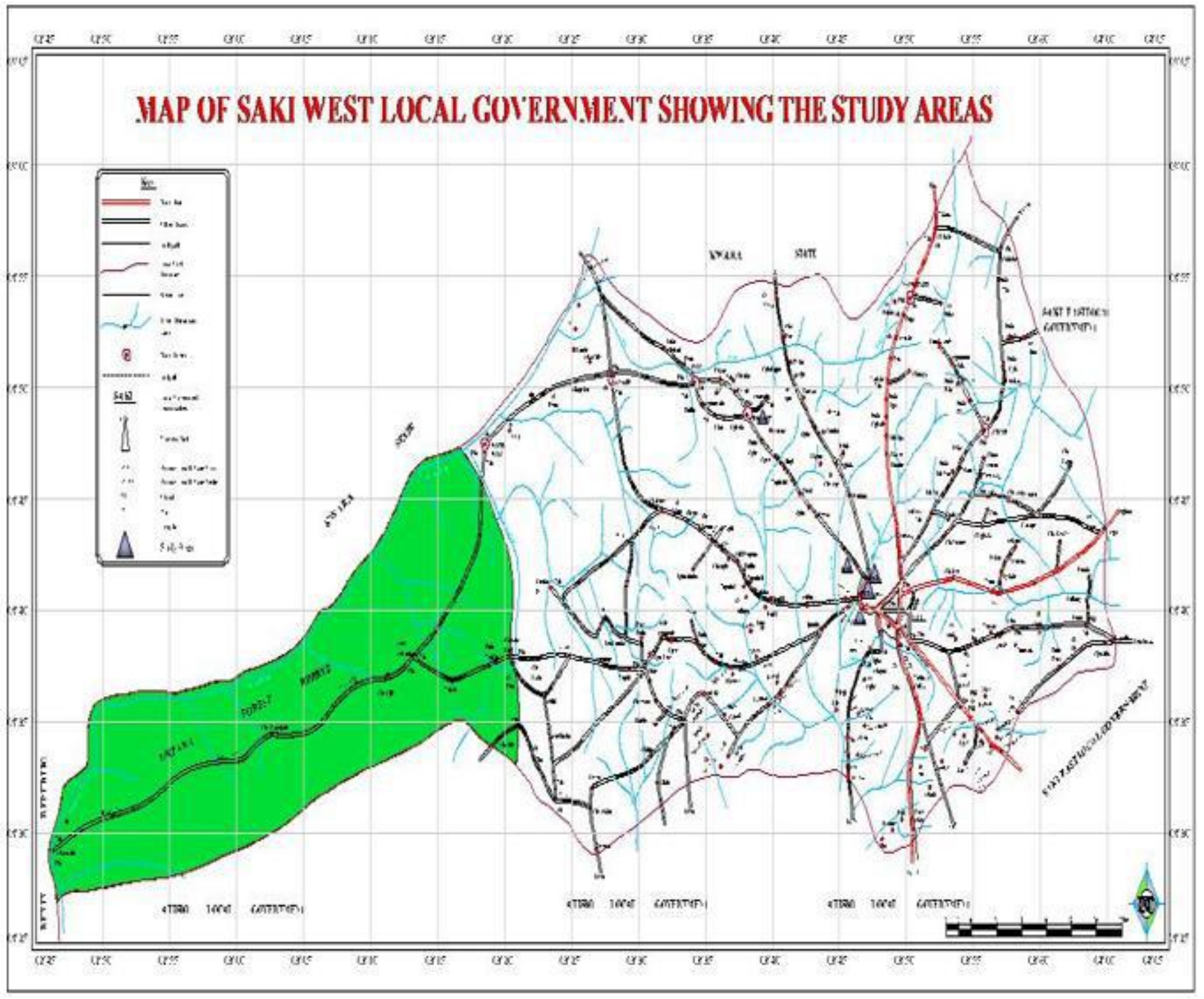

Fig. 2 
The area experiences North-East trade wind which brings harmattan between November to March being nearer to the Northern belt of the country. There is usually a drop in relative humidity during the period of harmattan. Primary and secondary data were used in the study. Primary data were generated through a set of well structured questionnaire administered on the processors at the eight processing centres. Purposive sampling approach was adopted to collect the data. One hundred and fifty (150) yam chips processors out of an estimated 165 processors were interviewed.

Data collected were age, education religion, occupation, gender, marital status and year of processing experience. Others include processing time, equipment quality and storage observations were also made about processing constraints, possible by products and environmental pollution. Secondary data were sourced from literature and relevant work in this area. Descriptive statistics tools (frequency distribution and percentage) were used to analyse the data collected from the study. Chi-square was used to examine the relationship between socio-economic characteristics of the processors and output.

\section{RESULTS}

Table.1: Distribution of Respondents according to Socio-economic Information

\begin{tabular}{|c|c|c|}
\hline Age & Frequency & Percentage \\
\hline $20-29$ & 35 & 23.33 \\
\hline $30-39$ & 40 & 26.67 \\
\hline $40-49$ & 46 & 30.67 \\
\hline $50-59$ & 20 & 13.33 \\
\hline $59-60$ & 09 & 6.00 \\
\hline Total & 150 & 100.00 \\
\hline \multicolumn{3}{|l|}{ Sex } \\
\hline Male & 08 & 5.33 \\
\hline Female & 142 & 94.67 \\
\hline Total & 150 & 100.00 \\
\hline \multicolumn{3}{|l|}{ Marital Status } \\
\hline Single & 30 & 20.00 \\
\hline Married & 112 & 75.67 \\
\hline Divorced & 08 & 5.33 \\
\hline Total & 150 & 100.00 \\
\hline \multicolumn{3}{|l|}{ Religion } \\
\hline Christianity & 15 & 10.00 \\
\hline Islamic & 127 & 84.67 \\
\hline Traditionalist & 08 & 5.33 \\
\hline Total & 150 & 100.00 \\
\hline \multicolumn{3}{|l|}{ Educational Level } \\
\hline No formal education & 38 & 25.33 \\
\hline Primary Six Leaving Cert. & 45 & 30.00 \\
\hline $\begin{array}{l}\text { Junior and Secondary School } \\
\text { Education }\end{array}$ & 64 & 42.66 \\
\hline $\begin{array}{l}\text { Tertiary Education (Polytechnic, } \\
\text { College of Education and } \\
\text { University) }\end{array}$ & 03 & 2.00 \\
\hline Total & 150 & 100.00 \\
\hline \multicolumn{3}{|l|}{ Labour Man/ Days } \\
\hline Family & 50 & 33.3 \\
\hline Hired & 100 & 66.7 \\
\hline Total & 150 & 100 \\
\hline Year of Experience & & \\
\hline
\end{tabular}




\begin{tabular}{|l|l|l|}
\hline $1-5$ & 45 & 30.0 \\
\hline $6-10$ & 60 & 40.0 \\
\hline $11-15$ & 28 & 18.67 \\
\hline $16-20$ & 12 & 08.0 \\
\hline $21-25$ & 5 & 3.33 \\
\hline Total & $\mathbf{1 5 0}$ & $\mathbf{1 0 0 . 0 0}$ \\
\hline Output in Bags & & \\
\hline Below 10 bags & 02 & 1.33 \\
\hline $10-20$ bags & 15 & 10.0 \\
\hline $20-30$ bags & 28 & 18.67 \\
\hline $30-40$ bags & 32 & 21.33 \\
\hline $40-50$ bags & 48 & 32.00 \\
\hline Above 50 bags & 25 & 16.67 \\
\hline Total & $\mathbf{1 5 0}$ & $\mathbf{1 0 0 . 0 0}$ \\
\hline
\end{tabular}

\section{Source: Field survey 2011}

Table.2: Relationship between Socio-economic Characteristics and Output of the Processors

\begin{tabular}{|l|l|l|l|l|}
\hline & \multicolumn{4}{|l|}{ Value of level of Significance } \\
\hline Output and Age & 0.534 & 2 & 0.034 & NS \\
\hline Output and Marital Status & 0.098 & 2 & 0.20 & NS \\
\hline Output and Educational Background & 2.897 & 4 & 0.010 & NS \\
\hline Output and Religion & 1.543 & 2 & 0.010 & NS \\
\hline
\end{tabular}

Table.3: Distribution of Respondents according to Production Output

\begin{tabular}{|l|l|l|}
\hline Variable & Frequency & Percentage \\
\hline High (Above 50) & 25 & 16.67 \\
\hline Medium (31-50) & 80 & 53.00 \\
\hline Low (Below 30) & 45 & 29.00 \\
\hline
\end{tabular}

\section{DISCUSSION}

\section{Socio-economic Factors of the Processors}

a. Sex of the Processors: Ninety-fivepercent of the processors were females while the remaining five percent are males who were mostly the children of the processors who do assist in the peeling of the yams and fetching for process. Thus finding supports the earlier findings reported by Sanni (1991), Olatoye (1989), NEST (1991), Siyanbola and Elegbede (2010).

b. Age of the Processors: The age of the processors fall within 20 -60 years, however, majority of them fall between $20-49$ years which constitute $87 \%$ of the total respondents. This implies that most of the respondents are still in their active age. The respondents are at their economically active age and are still in child bearing age. Age is one of the factors affecting decisions and actions made in agriculture, because people thought, behaviours and needs are primarily related to their ages.(Simsek and Karkacur,1996) .

c. Marital Status: Majority of the processors were married (seventy -six percent) which is an indication that most of the respondents have another responsibility outside their income earning occupation such as domestic work and other manual responsibility in line with the observation made by FAO,2009.

d. Education Background: Studies have revealed that education influences the adoption of practices in modern Agriculture (Obinne, 1991) The reason been that educated person is more likely to adopt modern practices easily, better innovation $\mathrm{s}$ and hence could be a better producer. It is expected that the years of education will contribute significantly to decision making of a farmer. The findings support Obinne 1991; Alabi and Aruna 2006 and Ndahitisa 2008 that years of education determiners the quality of skills of farmers, their allocative abilities and how well informed they are to the innovators and technologies around them. Also support the result of Oladipo and Adekunle 2010 that individual $\mathrm{s}$ with higher educational attainment are usually being faster adopters of innovation. 
This survey revealed that seventy-five percent of the processors are educated. However, the level of education varied from primary to secondary and tertiary institutions. The percentage of those with no formal education is about $25 \%$. This shows that majority of the processors were educated. This can be accounted for through the free education of Obafemi Awolowo in the Western region coupled with renewed interest of Nigerians in Western education through various awareness campaigns. The high percentage of literates among the processors implies that the processors can easily adopt new techniques of yam chips processing when introduced.

e. Labour: Labour is expressed as adult male man - day and it is the summation of family labour and hired labour. Family and hired labour play an important role in agricultural production especially in developing economics where capital is less significant (Meire, 1989). The result showed that majority (63\%) of the processors in the study area use more of family labour so as to maximize profit. The implication of this study is that processors will be spending less than hired labour.

f. Year of Experience: The highest year of experience was 30 years and the least 2 years.

This implies that more women were involved in the processing in the last 10 years. This may be due to the high unemployment rate in the country presently experience in the country with over 55\% of Nigerians of working age unemployed (Financial Standard, June 2009) representing one in five adults.

The knowledge, skill and practices acquired over a certain period that is accrued to farmers in practice. The result majorly falls between 6 and10 years which agrees with the work of Oluwatayo et al 2008 that farmers with more experience would be more efficient, have better knowledge of climatic conditions and market situation and are thus expected to run a more efficient and profitable enterprise.

$\mathrm{He}$ also supports findings of Onyebinamci, 2004 that previous experience in farm business management enables farmers to set realistic time and cost targets, allocate, combine and utilize resources efficiently and identify production skills.

g. Medium of Training of Processors: Most of the processors had no formal training in yam chips processing. Majority (98\%) as indicated during the survey acquire the skill from friends and relatives. Nobody indicated in the questionnaire that they receive any training through media or Agricultural Extension Agents.

h. Processing Time, Techniques and Packaging: The period of processing ranges from 1 - 10 days depending on the availability of labour (usually children of processors and hired labours) and intensity of sun. The processing period is shorter (3-4 days) during the peak of harmattan (December to January). This is the peak of yam chips production in this region. The peeled yams are left on the flat rocks or bare ground at the processing sites. Majority of the processors use drums for pre-cooking $(85 \%)$ while only few use aluminum pots $(10 \%)$ for economic reason .The use of crude implements is because they lack collaterals to obtain loan since they generate capital for the yam chips production through informal sources (personal savings ,daily contributions and loan from friends and husband). At the time of the survey, the cost of a drum was \#2000.00 while the largest iron pot cost \#6000.00. The locally made clay pot costs \#800.00. However, only 5\% processors indicted that they make use of clay pots which is the cheapest during the survey but break easily and can only take small amount of chips compared to drum and aluminum pots. Some of the processors indicated that they use rust prone drums for pre-cooking and the use of unchanged water throughout the period of processing will obviously contaminate the chips but attendant health risk was not be assessed.

Eighty percent of the processors affirmed that yam tubers do not store well in fresh form and that transportation is costly due to their bulkiness hence processing into chips as reported by Okereke and Nwosu (1981). Dried yam chips are packed into bags of different sizes and kept in store for between 6-7 months. The weight of the bags ranges between $130 \mathrm{~kg}-$ $150 \mathrm{~kg}$. (Average weight is $140 \mathrm{~kg}$ ).

i. Output: The production rate is low (majority produce between $31-50$ bags) (53\%) during the processing period. This low production level of the women can be attributed to their marital status because they have other domestic responsibility therefore sharing their time between such responsibilities.

j. Useful by Products and Environmental Pollution: The peels from the yam tubers can be dried and use as feed to livestock. It can also be incorporated into feeds of poultry as a source of carbohydrate as reported by Siyanbola and Amao (2011). The peels form a heap of refuse around the processing centres but do not constitute any environmental pollution.

k. Occupational Hazards: The 3 common diseases that affect the processors as indicated by the processors are malaria, catarrh and cough. This may be due to their exposure to mosquitoes and cold at the processing sites.

l. Processing Constraints: The constraints highlighted 
by the processors are:

- Lack of capital to purchase yam tubers and purchase of stainless drums. They usually generated capital through informal sources such as personal savings, contribution and borrowing from friends.

- Inability to obtain loan from banks because of lack of collaterals especially landed properties.

- Security problem.

- Lack of shelter at the processing site.

- Lack of health facilities for processors and their children.

- Scarcity of labour.

- $\quad$ Lack of water needed for washing and parboiling of peeled yams since the processing period usually fall within the dry season.

- No incentives from government in form of agric loan, tools etc.

- Lack of adequate storage facilities and extension services.

The yam chips processors are women which supports the earlier findings that women are processors of farm produce (Sanni, 1991). The age of the processors falls within 20-60 yrs. This is an indication that most of the processors are within the productive age. The mean number of years of schooling was about 14 years while the highest year of experience was 25years. This implies that most of the processors are literate and with years of experiences which influences decision making in relation to risk aversion.(Asumugha et al (2009). The period of processing observed is from 1-10 days depending on availability of labour and time of processing. During the peak of harmattan period (December - March), it takes a shorter period for the chips to get dry for storage. The use of rust prone drums for the cooking will obviously contaminate the chips but the attendant health risk was not assessed. Majority of the processors $(80 \%)$ affirmed the yam tubers do not store well in fresh form and that transportation is costly due to their bulkiness. This correlates with reported findings by Charke (1987;Martins (1972) and Ekechhukwe et al (1987).The processors had earlier identified some constraints affecting yam chips processing to be bad road to the processing centers, drudgery of processing, lack of capital for expansion of their activities and environmental conditions

\section{Conclusions and Recommendations.}

Yam chips processing in the study area are neither subsistence traditional nor village level but it is a welldeveloped commercial enterprise. Majority of the processors are women with formal education. Yam chips production is relatively simple and calls for no major investment and moreover provides an effective means for producers to boost the value of the crop. The processing of yam tubers into chips will assist in stabilizing market prices thus reducing loss of tubers and provides farmers a safe return with the opportunity to grow more tubers. Women groups should be encouraged and strengthened through the provision of credit facilities extension services, agricultural inputs, processing ,storage and marketing services that will assist to increase production. The entire production and marketing chain offer vast employment opportunities. It also offers prospects for income generation due to the numbers of people involved and the value attached to it. Moreover, the role of women in food production processing and marketing has become more relevant as a way of fighting poverty and ensuring food security.

However, in attaining the Millennium Development Goals (MDGs) of helping those living in poverty and eliminating hunger by 2015 there need for the government to assist the processors by;

- Public enlightenment to educate the processors on ways of improving the quality of their products.

- Provision of stainless drums at subsidized rates.

- Provision of health facilities at the processing centers.

- Giving interest free loan to processors.

- Construction of model processing centers.

- Construction of roads to the processing centers.

- Processors to have access to extension services in order to improve their knowledge of farm management and the need to form cooperative societies.

- $\quad$ Provision of storage facilities.

\section{REFERENCES}

[1] Alabi, R.A. and Aruna M.B. (2006). Technical Efficiency of Family Poultry Production in Niger Delta, Nigeria - Journal Central European Agriculture 6(4): $531-538$.

[2] Akissoe, N.H., Hounhougan, J.D., Brica, N., Vierner, P., Nago, M.C. and Olorunda, O.A. and (2003). Physical, chemical and sensory evaluation of dried (Dioscorea rotundata) tubers, Flouramala - a flour derived product. Trop Sci. 41, pp. 151-156.

[3] Coursey, D.G. (1967). Yams. Longmans. Green London.

[4] Coursey, D.G. and Coursey, C.K. (1971). The new yam festivals of West Africa. Antropos 66, pp. 444-484.

[5] Ezeh,N.O (1992) Economics of yam production :implications for research and development and promotion of yam based industries in Nigeria Pp303- 
305.In proceedings of $4^{\text {th }}$ AB-ISTRCSymposium ,5-8 December, 1989 Kinshasa, Zaire .

[6] F.A.O. (1991). Fish for Food and Employment. Food and Agricultural Organisation. Rome.

[7] Financial Standard, June 2009.

[8] Food and Agriculture Organisation (FAO) (1987). Formulation reports. Roots and tubers expansion programme. FAO Rome Italy.

[9] Food and Agriculture Organisation FAO (1997). Food production year book. Food and Agriculture organizations. Rome Vol. 50.

[10] Food and Agriculture Organisation FAO (1999). Food and Nutrition, creating a well fed world. FAO Rome Italy.

[11] Food and Agriculture Organisation FAO (2006). Food and Agricultural Organisation (2006). Data base.

[12] Food and Agriculture Organisation (2009). Improving the relevance and effectiveness of Agriculture Extension Activities. Retrieved Oct12, 2009. From http:///wwwfao.org/Docrep.//.48054/V4805co2.htm.

[13] Food and Agriculture Organisation (2010). Food and Agricultural Organisation FAOSTATDATA FAO, Rome: Italy.

[14]Hahn, S.K. Osiro, D.S.O., Akoroda, M.O. Otoo, J.A. (1987). Yam production and its future prospects outlook agric, 16.8 .

[15] Kudi, T.M., Bako, F.P. and Atala, T.K. (2008) Economics of Fish Production in Kaduna State Nigeria, ARPN Journal of Agricultural and Biological Science 3(5\&6): $17-21$.

[16] Mayong, V.G. and Oyewole, B. (1997). Spatial patterns of biological constraints to cassava and yam production in West and Central Africa. Implications for technology and development and transfer. Afr. J. Root Tuber Crops, 3(11), 50-53.

[17] Meier, G (1989): Leading Issues in Economic Development $5^{\text {th }}$ Edition Oxford Unversity Press.

[18] National Environmental Study Team Environment (NEST) (1991). Nigerians threatened environment. A national profile. Nigeria Environmental Study/Action Team pp. 44-48.

[19] Ndahitsa, M.A. (2008): Impact of Small Scale Irrigation Technologies on Crop Production by Fadama Users in Niger State, $10^{\text {th }}$ National Conference of National Associaton of Agricultural Economics held at the University of Abuja Pgs. 195.

[20] Obinne, C.P.O. (1991): “Adoption of Improve Cassava Production Technolgies by Small Farmers in Bendel State". African Journal of Biotechnology 7(9): 1227 1286.
[21] Ojokoh, A.O. and Gabriel, R.A. (2010). A comparative study on the storage of yam chips (gbodo) and yam flour (elubo). Afr. Journal of Biotechnology. Vol. 9(21), pgs. 3175-3177.

[22] Olatoye, D. (1989). "Storage: The missing link" in the Republic, Friday June 23rd 1989.

[23] Oluwatayo, I.B., Sekumade, A.B. and Adesoji,S.A. (2008). Resource use Efficiency of Maize Farmers in Rural Nigeria. Evidence from Ekiti State. World Journal of Agricultural Science4(1): 91 - 99.

[24] Onyebinama, U.A.U., (2004): Farmer Business Management for Smallholder Farm Firms in Owerri, Owerri Alphabet Nigeria Publishers, Nigeria.

[25] Osisiogu, I.U., and Uzo J.O (1973). Industrial potential of some Nigeria Yam and cocoyam starches. Tropical Science, 15:pp. 353-359.

[26] Sani, R.N., Musa, S.A., Dareji M.I. Yakasai, M.T. and Ayodele (2007): Cost and Return Analysis in poultry Production in Bauchi and Gombe Metropolis Area.Continental Journal of Agricultural Economics 1: $14-19$.

[27] Simek, D. and Kakacur, O. (1996): A Study on Socio Economic Affecting the Adoption of Agricultural Innovations in Rural Regions Paper Presented at the $14^{\text {th }}$ International

[28] Congress of Mediterranean Federation Health and Production of Ruminants $15^{\text {th }}-19^{\text {th }} 1996$.

[29] Siyanbola ,M .and Elegbede O. (2010). Food Security and Nigeria Rural Women. Journal of Women in Technical Education. Vol. 6, No. 2, 205-213.

[30] Siyanbola, M.F. and Amao, E.A. (2011). Effect of replacement of yam (Dioscorea spp) peel meal for maize (Zea may) on growth performance, carcass characteristics and blood chemistry of finisher broilers. Journal of Agriculture and Biological Sciences Vol. 2(1), pp. 18-21. 